\title{
Comparative Heavy Metal Removal Efficiencies of Biosurfactants Produced by Odoribacter Splanchnicus DSM 20712, Bacterium Clone JX981747 and Soil Washing Agents
}

T00CHUKWU Ekwutosi Ogbulie ( $\nabla$ ogbulie.toochi@gmail.com )

Federal University of Technology Owerri https://orcid.org/0000-0003-1491-9002

Chioma Chimezie Okore

Department of Environmental Biology, Federal Polytechnic Nekede Owerri, Imo-State, Nigeria Agunna Everest Ejele

Department of Chemistry, Federal University of Technology Owerri, Imo-State, Nigeria

\section{Research}

Keywords: Biosurfactants, Gas chromatography, heavy metals, paper chromatography, soil washing, bacteria, chelators

Posted Date: May 20th, 2020

DOl: https://doi.org/10.21203/rs.3.rs-26833/v1

License: (c) (1) This work is licensed under a Creative Commons Attribution 4.0 International License.

Read Full License 


\section{Abstract}

The application of two biosurfactants in the removal of copper, zinc, and lead from waste metal dumpsite soil with their efficiencies was compared to soil washing agents as $\mathrm{KNO}_{3}, \mathrm{Ca}\left(\mathrm{NO}_{3}\right)_{2}$ and $\mathrm{NaOH}$. The test soil samples were also spiked separately with different concentrations $(50 \mathrm{mg} / \mathrm{L}, 250 \mathrm{mg} / \mathrm{L}, 750 \mathrm{mg} / \mathrm{L}$ and $1500 \mathrm{mg} / \mathrm{L}$ ) of $\mathrm{CuSO}_{4}, \mathrm{ZnSO}_{4}$ and $\mathrm{Pb}\left(\mathrm{NO}_{3}\right)_{2}$. The biosurfactants used were produced by Odoribacter splanchnicus DSM 20712 (WBS1) and an unidentified bacterium clone JX981747 (CMS). Five different treatment set up comprising of different ratios $(20: 1,15: 1,10: 1,5: 1$, and 1:1) with the soil solution constant was respectively used. The heavy metal contents were measured using Atomic Absorption Spectrophotometer and the percentage heavy metal removal efficiency was calculated. The highest concentrations of biosurfactant (20:1) at different spiked concentrations of metallic salts recorded the highest values of copper $(95.47 \%, 95.73 \%, 91.69 \%, 78.82 \%)$; zinc $(97.98 \%, 98.98 \%, 97.29 \%, 96.78 \%)$ and lead $(97.68 \%, 93.09 \%, 88.12 \%, 84.98 \%)$ removal. The percentage metal removed in each treatment increased with increasing concentration of the biosurfactants and washing agents (1:1 to 20:1). The chemical structure of the two biosurfactants analyzed using Gas Chromatography Mass Spectroscopy (GC-MS) depict the major component of biosurfactants produced from Odoribacter splanchnicus DSM 20712 to be Di-n- amyl phthalate while 9, Octadecanoic acid, methyl ester was from unidentified bacterium clone JX981747. The one dimensional paper chromatography showed presence of galactose/glucose, mannose, ribose, rhamnose in the biosurfactants produced from Odoribacter splanchnicus DSM 20712 whereas the unidentified bacterium clone JX981747 produced biosurfactants that contained all sugars except mannose. The test biosurfactants studied showed high levels of copper and lead removal than zinc when compared with the test soil washing agents $\left(\mathrm{KNO}_{3}\right), \mathrm{Ca}(\mathrm{NO} 3)_{2}$ and $\mathrm{NaOH}$ used in this study. Biosurfactants have thus shown to have the ability to remove metals hence its use requires scaling up for environmental applications.

\section{Introduction}

Soils may become contaminated by the accumulation of heavy metals and metalloids through emissions from the rapidly expanding industrial areas, mine tailings, disposal of high metal wastes, leaded gasoline and paints, land application of fertilizers, animal manures, sewage sludge, pesticides, wastewater irrigation, coal combustion residues, spillage of petrochemicals, hospital effluents, hospital wastes and atmospheric deposition (Roane et al., 1996; Khan et al., 2008; Zhang et al., 2010). Heavy metals constitute an ill-defined group of inorganic chemical hazards, and those most commonly found at contaminated sites are lead $(\mathrm{Pb})$, chromium (Cr), arsenic (As), zinc ( $\mathrm{Zn})$, cadmium (Cd), copper (Cu), mercury $(\mathrm{Hg})$, and nickel $(\mathrm{Ni})$ (Ogbulie, 2011). Soils are the major sink for heavy metals released into the environment by aforementioned anthropogenic activities (Ogbulie et al., 2010) and unlike organic contaminants which are oxidized to carbon (IV) oxide by microbial action, most metals do not undergo microbial or chemical degradation (Kirpichtchikova et al., 2006), and their total concentration in soils persists for a long time after their introduction (Adriano et al., 2003). There may be changes in their 
chemical forms (speciation) and bioavailability of which soil characterization would provide an insight into these heavy metal speciation and bioavailability (Zhao and Kaluarachchi, 2002).

The effectiveness of washing is closely related to the ability of the extracting solution to dissolve the metal contaminants in soils. However, the strong bonds between the soil and metals make the cleaning process difficult (Gombert, 1994). Owing to the different nature of heavy metals, extracting solutions that can optimally remove them must be carefully sought during soil washing. Several classes of chemicals used for soil washing include surfactants, cosolvents, cyclodextrins, chelating agents, and organic acids (USEPA, 1990; Wood et al., 1990; Chu and Chan, 2003; Gao et al., 2003; Maturi and Reddy, 2008; Zhang et al., 2009). All these soil washing extractants have been developed on a case-by-case basis depending on the contaminant type at a particular site. A few studies have indicated that the solubilization/exchange/extraction of heavy metals by washing solutions differs considerably for different soil types. Surfactants are used on a large scale basis worldwide in everyday household use to industrial cleaning and textile manufacturing. Surfactants are best known for their solubility and cleaning properties which secured them a place among detergents and other cleaning products (Ivanković and Hrenović, 2010). Synthetic detergents used to clean up spillages have often led to more destruction of the environment from an environmental view point (Ogbulie et al., 2008). It is important that the remediation process be as non destructive and environmentally benign as possible if the end product is intended to be a healthy productive ecosystem. Metal-contaminated sites vary according to location, the source of metal contamination, and the history and age of the metal contamination. We had studied the removal of metals from metal dumpsite soil using biosurfactants and other soil washing agents. The metal dumpsite soil is a sink for metals (copper, zinc, lead) and it has a long history of contamination with these metals (Okore, 2017a; b).

Chelators are chemical compounds that form complexes with metal ions or other substances and also called chelating agents or sequestering agents. The chelating agent has a ring like center, which forms a complex with the metal ion/substance by two or more bindings and the metal ion is bound and extracted. There are a great number of metal chelators few of these materials are environmentally benign; the acids, alkalis, complexants, other solvents and surfactants examples $\mathrm{KNO}_{3}, \mathrm{Ca}\left(\mathrm{NO}_{3}\right)_{2}$ and $\mathrm{NaOH}$ (Dermont et al., 2008). The synthetic chemicals such as nitrilotriacetic (NTA), ethylenediamine-tetraacetic acid (EDTA), and diethyl triamine pentaacetic acid (DTPA) are extremely effective at metal complexation. Their xenobiotic nature makes persist in the environment long after they are applied for a remedial measure, pose a threat to the aquatic environment and some are comparatively more toxic to human health. Their use in the field for in-situ removal is questionable because of their demonstrated toxicity effects. The strong acids attack and degrade the soil crystalline structure at extended contact times (Dehghan-Noudeh et al., 2005).

The aqueous solutions of biosurfactants can be used to release compounds characterized by low solubility from soil and other media in process called washing. Soil washing performance is highly sensitive to site conditions. The process is most efficient when applied to soils and sediments containing large proportions of sand and gravel and is relatively ineffective when applied to soils having a high silt 
and clay content. Further, soils with a relatively high cation exchange capacity (the capacity to exchange cations for those in the polluting substances) tend to bind pollutants more tightly, which can limit the ability of the soil washing process to effectively separate the pollutants from the soil (Oberbremer et al., 1990; Fiebig et al., 1997; Yuste et al., 2000; Pacwa-Plociniczak et al., 2011; Kumari et al., 2012). Therefore, only extractants capable of dissolving large quantities of metals would be suitable for cleaning purposes (Tejowulan and Hendershot, 1998). The identification and quantification of coexisting solid metal species in the soil before and after treatment are essential to design and assess the efficiency of soil-washing technology (Kirpichtchikova et al., 2006).

The usefulness of biosurfactants for bioremediation of heavy metal contaminated soil is mainly based on their ability to form complexes with metals (Ogbulie, 2011). Metal ions are bound to oppositely charged ions or replace the same charged ions (electrostatic interactions or ion exchange) or complex with agents forming chelates on the polar head groups of micelle surface. This makes the metals more soluble in water. Biosurfactants used for soil treatment are also required to have minimal sorptive interactions applied to the soil system; in other words, most of the biosurfactant should remain in the aqueous phase. Biosurfactant sorption in general is likely the reason that high biosurfactant concentrations are required for effective metal removal (Asci et al., 2007; 2008). Logically, the adsorptive behavior of a biosurfactant will depend on their molecular characteristics, such as charge and hydrophobicity, as well as on the soil characteristics. It is important that all substances released into the environment be degradable. Their potential for causing environmental damage should be assessed and the possibility of future harm due to build-up in the environment should be taken into consideration. This study was designed to characterize the biosurfactants produced from Odoribacter splanchnicus DSM20712 and unidentified bacterium clone JX981747 with a view to ascertain their metal removal efficiencies and to compare the metal removal efficiencies with some soil washing agents as $\mathrm{KNO}_{3}$, $\mathrm{Ca}\left(\mathrm{NO}_{3}\right)_{2}$ and $\mathrm{NaOH}$.

\section{Methodology}

\section{Isolation, screening and identification biosurfactant producing-bacteria}

The bacteria species were isolated from waste battery dumpsite soil and cassava mill soil collected at Nekede Imo State, Nigeria. The bacteria species were identified by 16S rRNA gene in lquaba, Pittsburg, South Africa. Both bacteria were screened for biosurfactant production using emulsification index test, oil displacement test and $\beta$ hemolysis test using methods described by Okore et al., (2017 a,b,c)

\section{Production and extraction of crude biosurfactant}

The colonies of Odoribacter splanchnicus DSM 20712 isolated from WBS and an unidentified bacterium clone JX981747 form CMS were inoculated in $500 \mathrm{ml}$ nutrient broth medium in $1000 \mathrm{ml}$ Erlenmeyer flask 
and incubated at $30^{\circ} \mathrm{C}$ for 7 days on a mechanical shaker. After 1 week of incubation, it was filtered by centrifugation for $45 \mathrm{~min}$ at $4,000 \mathrm{Xg}$ to obtain cell free supernatant and sediments of cell debris. The extraction was performed by acid precipitation with $1 \mathrm{M} \mathrm{H}_{2} \mathrm{SO}_{4}$ of equal volume to attain a $\mathrm{pH}$ of 2.0 (54.3 $\mathrm{ml}$ conc. $\mathrm{H}_{2} \mathrm{SO}_{4}$ poured into $1 \mathrm{~L}$ distilled water $=1 \mathrm{M} \mathrm{H}_{2} \mathrm{SO}_{4}$ ). This was put in the fridge $\left(4^{\circ} \mathrm{C}\right.$ ) overnight for complete precipitation of the biosurfactant. After $24 \mathrm{~h}$ it was centrifuged at $4,000 \mathrm{X} \mathrm{g}$ for 45 min to sediment the biosurfactant. The supernatant was filtered off and the sediment stirred continuously for 20 min after which GC-MS chemical analysis and one dimensional paper chromatography was carried out.

\section{Chemical characterization of produced biosurfactant i. Gas chromatography-Mass Spectrometer}

The partially purified biosurfactant obtained as sediment was mixed with chloroform and the chemical component analyzed using Gas chromatography-Mass Spectrometer (GC-MS).

\section{ii. Sugar detection}

One dimensional paper chromatography (AOAC, 2005) was employed. The crude biosurfactant was reconstituted in $1 \mathrm{ml}$ of sterile distilled water and hydrolysed by boiling in $5 \mathrm{ml}$ of bench sulphuric acid solution (2 M). The hydrolysate was spotted on Whatman chromatographic paper and ran in two separate solvents Butanol-Acetic acid-Water, 4:1:5 (BAW) and Butanol-Ethanol-Water, 4:1:2.2 (BEW). The separate chromatographs were allowed to run for 18-24 $\mathrm{h}$ and the paper was removed and dipped in aniline hydrogen phthalate solution in 1:1 ether: butanol solution. It was then dried for $5 \mathrm{~min}$ at $105^{\circ} \mathrm{C}$ and viewed under UV light and the various spots were marked. The relative fronts ( $\mathrm{rfs}$ ) were calculated and matched against standard relative fronts for sugars (RFS). The matching sugars were deemed detected.

\section{iii. Protein detection}

The tests for protein by Ninhydrin and Biuret were based on the standard method of Association of Official Analytical Chemists (AOAC 2005). In Ninhydrin test, $2 \mathrm{ml}$ of sample mixed with $2 \mathrm{ml}$ of Ninhydrin solution was heated, the development of liliac or faint blue colour is positive for presence of protein. In Biuret test, $2 \mathrm{ml}$ of sample was mixed with $2 \mathrm{ml}$ Biuret reagent, the development of purple or violet colour shows presence of protein.

\section{Heavy metal removal from spiked contaminated soil}

The experimental set up was done using the soil samples collected from waste metal dumpsite soil spiked with solutions of different concentrations of the metallic salts $\left(\mathrm{Pb}\left(\mathrm{NO}_{3}\right)_{2}, \mathrm{Cu}(\mathrm{SO})_{4}\right.$, and $\mathrm{Zn}(\mathrm{SO})_{4}$ using the modified methods of Mulligan et al., (1999) and Maier et al., (2001). The metallic solutions was prepared by dissolving $50 \mathrm{mg}, 250 \mathrm{mg}, 750 \mathrm{mg}$ and $1500 \mathrm{mg}$ each of $\mathrm{Cu}\left(\mathrm{SO}_{4}\right)_{2}, \mathrm{~Pb}\left(\mathrm{NO}_{3}\right)_{2}$ and $\mathrm{Zn}\left(\mathrm{SO}_{4}\right)_{2}$ separately in $1 \mathrm{~L}$ distilled water. The Atomic Absorption Spectrophotometer 
(AAS) reading of the various metallic concentrations was analyzed. Then $1 \mathrm{~g}$ of the soil sample from waste metal dump site was added to equal volumes of each concentrations of the metallic solution $(5 \mathrm{ml})$. Thereafter it was centrifuged and supernatant subjected to AAS for the metal content determination. The results served as the initial metal content without biosurfactant treatment. The biosurfactant producing isolates Odoribacter splanchnicus DSM 20712 and the unidentified bacterium clone JX981747 were inoculated into nutrient broth and left for 7 days on the mechanical shaker. Thereafter the broth was centrifuged to separate the bacterial cells from the biosurfactant containing supernatant. The heavy metal removal of the spiked soils with biosurfactant was carried out using soil metallic solution to biosurfactant ratios $(1: 1,1: 5 ; 1: 10 ; 1: 15$ and 1:20). The soil metallic solution with biosurfactant was shaken and left for 3 days. Then the soil was removed by centrifugation ( $4000 \mathrm{X} \mathrm{g}$, $25 \mathrm{~min}$ ) and dried. The supernatant was removed and placed into another centrifuge tubes acidified with 5 drops of $\mathrm{HNO}_{3}$ to precipitate the biosurfactant then refrigerated for $24 \mathrm{~h}$. After refrigeration the precipitated biosurfactant was removed from solution by centrifugation at ( $4000 \mathrm{X} \mathrm{g}, 25 \mathrm{~min})$. Then the supernatant analyzed for the metal content using AAS. The amount of metals extracted from the soil by each biosurfactant was then calculated as a percentage of the original metal concentration without biosurfactant using the formula below.

$$
\text { Percentage metal removal }=\frac{\mathrm{A}-\mathrm{B} X}{\mathrm{~A}} \quad 100 \%
$$

Key: $\mathrm{A}=$ the amount of metal originally in the soil

$\mathrm{B}=$ the amount of metal left in the supernatant

\section{Soil washing of heavy metal contaminated soils (un-spiked)}

This was carried out using the method of Mulligan et al., (1999) and Rufino et al., (2011) with modifications. The test soil samples $(10 \mathrm{~g})$ dried at room temperature was digested over low flame for $15 \mathrm{~min}$. This was done by initial heating for $3 \mathrm{~min}$ with $10 \mathrm{ml}$ of $\mathrm{H}_{2} \mathrm{O}_{2}$, then another $5 \mathrm{ml}$ of $\mathrm{H}_{2} \mathrm{O}_{2}$ for another $3 \mathrm{~min}$, followed by $5 \mathrm{ml}$ of $\mathrm{H}_{2} \mathrm{O}_{2}$ and heating for $3 \mathrm{~min}$. Thereafter $70 \mathrm{ml}$ of concentrated $\mathrm{H}_{2} \mathrm{SO}_{4}$ was added and heated for 6 min before the sample will be removed from the heat for cooling. Distilled water was added after cooling to make up the volume to $400 \mathrm{ml}$. The soil sample supernatant was collected after votexing to attain an equilibrium and centrifuged ( $5000 \mathrm{Xg} 10 \mathrm{~min}$ ). The supernatant was then filtered through a $0.2 \mu \mathrm{m}$ cellulose acetate filter prior to AAS analysis for metal concentration and this served as the amount of metal originally in the soil sample supernatant. The biosurfactant producing isolate was inoculated into $1000 \mathrm{ml}$ nutrient broth and left for 7 days on mechanical shaker. Thereafter the broth was centrifuged at 4,000 X g 45 min to sediment the bacterial cell and the supernatant used for the soil washings studies. The soil washing with biosurfactant study was carried out using soil sample supernatant to biosurfactant ratios ranging from 1:1 to $20: 1$ in acid washed plastic centrifuge tubes of $50 \mathrm{ml}$ without varying the $\mathrm{pH}$. The comparison experiment was set up using aqueous solution of similar ionic strength like $\mathrm{KNO}_{3}, \mathrm{Ca}\left(\mathrm{NO}_{3}\right)_{2}$ and $\mathrm{NaOH}$. The experimental set up was left for 1 week before AAS analysis to ascertain the amount of heavy metal left in the supernatant after centrifugation. The percentage of metal removal was calculated using similar equation as above: 
Percentage metal removal $=\underline{\mathrm{A}-\mathrm{B} X} \quad 100 \%$

Key: $A=$ the amount of metal originally in the soil

$\mathrm{B}=$ the amount of metal left in the supernatant

\section{Results}

\section{Screening and Identification}

The $\mathrm{E}_{24}$ of biosurfactants from Odoribacter splanchnicus DSM 20712 recorded is $78.13 \%$ on kerosene while the $E_{24}$ of the biosurfactants from an unidentified bacterium clone JX981747is $68.52 \%$ on power vegetable oil and $57.41 \%$ on crude oil. Both isolates exhibited positive $\beta$ hemolysis and displaced hydrocarbons used in the oil displacement test (Table 1).

Table 1: Screening test for biosurfactant production

\begin{tabular}{|c|c|c|c|c|c|c|c|c|c|c|c|c|}
\hline \multirow[t]{2}{*}{$\mathrm{S} / \mathrm{N}$} & \multirow[t]{2}{*}{ Isolate } & \multirow{2}{*}{$\begin{array}{l}\beta \\
\text { Hemolysis }\end{array}$} & \multicolumn{5}{|c|}{ Emulsification index (E24\%) on Hydrocarbon } & \multicolumn{5}{|c|}{ Oil displacement test on hydrocarbon (cm) } \\
\hline & & & Kerosene & $\begin{array}{l}\text { Crude } \\
\text { oil }\end{array}$ & $\begin{array}{l}\text { Vegetable } \\
\text { oil }\end{array}$ & Petrol & Diesel & Kerosene & $\begin{array}{l}\text { Crude } \\
\text { oil }\end{array}$ & $\begin{array}{l}\text { Vegetable } \\
\text { oil }\end{array}$ & Petrol & Diesel \\
\hline 1 & WBS1 & +ve & 78.13 & 0 & 0 & 22.60 & 0 & 2.50 & 3.00 & - & 2.00 & 2.00 \\
\hline 2 & CMS1 & +ve & 0 & 57.41 & 68.52 & 28.00 & 0 & - & 2.00 & - & - & - \\
\hline
\end{tabular}

Key: $\quad$ WBS1 = Odoribacter splanchnicus DSM20712 from waste battery dump site

CMS1 = unidentified bacterium clone JX981747 from cassava mill soil

\section{Production and extraction of crude biosurfactant}

The quantity of crude biosurfactant produced from the $500 \mathrm{ml}$ broth culture of biosurfactants from Odoribacter splanchnicus DSM 20712 and unidentified bacterium clone JX981747 was respectively $1.53 \mathrm{~g}$ and $1.33 \mathrm{~g}$ after acid precipitation (Table 2).

Table 2: Yield of biosurfactant produced by WBS1 and CMS1

\begin{tabular}{lll}
\hline Isolate & Volume of broth culture (ml) & Weight of biosurfactant (g) \\
\hline WBS1 & 500 & 1.53 \\
CMS1 & 500 & 1.33 \\
\hline
\end{tabular}

Key: WBS1 = Odoribacter splanchnicus DSM 20712 from waste battery dump site soil CMS1 = unidentified bacterium clone JX981747 from cassava mill soil

\section{Chemical characterization of produced biosurfactants}

\section{1) Gas chromatography analysis}

A chromatogram depicting the real time of peaks generated as the separate components pass through the detector was recorded. The GC-MS fatty acids analysis of Odoribacter splanchnicus DSM 20712 
showed peaks each corresponding to long chain poly aliphatic and unsaturated compounds consistent with fatty acid methyl esters linked with benzene ring (Table 3). On the other hand, the GC-MS fatty acids analysis of the unidentified bacterium clone JX981747showed peaks corresponding to long chain poly aliphatic and unsaturated compounds consistent with fatty acid methyl esters linked mainly with Decanoic acid (Table 4).

The chromatograms of the biosurfactants produced by both test isolates are as shown in Figs. 1 and 2 respectively depicting a major peak of the likely compound at varying retention times (Odoribacter splanchnicus DSM 20712: Retention time of 12.470; an unidentified bacterium clone JX981747: Retention time of 13.705) whereas the other low peaks are the contaminants.

The Gas Chromatography library search result of biosurfactants produced by the test isolates showed the retention times of compounds detected, the components that exhibited peaks, their individual mass spectrum and chemical structures as shown on Tables 3 , and Table 4 for each of the respective biosurfactants.

\section{Sugar test}

The presence of these sugars (Tables 5 and 6) Glucose/Galactose, Mannose, Ribose, Rhamnose, were found in biosurfactant from Odoribacter splanchnicus DSM 20712, Glucose/Galactose, Ribose and Rhamnose found in biosurfactant from the unidentified bacterium clone JX981747. This result was confirmed from the two mobile solvents used in the one dimensional paper chromatography method.

\section{Protein test}

Tests for protein by Ninhydrin and Biuret both show faint colours hence indicating traces of protein. The same result was obtained for both samples.

\section{Metal analysis result on spiked soil}

The percentage metal removed increased with higher concentrations of the biosurfactants used. Copper recovery rates were as high as $95.47 \%, 95.73 \%, 91.69 \%$ and $78.82 \%$ in solutions respectively spiked with $50 \mathrm{mg} / \mathrm{L}, 250 \mathrm{mg} / \mathrm{L}, 750 \mathrm{mg} / \mathrm{L}$ and $1500 \mathrm{mg} / \mathrm{L}$ of copper and treated with 20:1 concentration of biosurfactant produced by Odoribacter splanchnicus DSM 20712 (Fig. 3a). Figure 4b also showed that $97.98 \%, 98.98 \%, 97.29 \%$ and $96.78 \%$ of Zinc was recovered in solutions spiked with $50 \mathrm{mg} / \mathrm{L}, 250 \mathrm{mg} / \mathrm{L}$, $750 \mathrm{mg} / \mathrm{L}$ and $1500 \mathrm{mg} / \mathrm{L}$ of zinc respectively and treated with 20:1 concentration of biosurfactant from an unidentified bacterium clone JX981747. Lead on the other hand equally recorded high recovery rates of $97.68 \%, 93.09 \%, 88.12 \%$ and $84.98 \%$ in solutions spiked with $50 \mathrm{mg} / \mathrm{L}, 250 \mathrm{mg} / \mathrm{L}, 750 \mathrm{mg} / \mathrm{L}$ and $1500 \mathrm{mg} / \mathrm{L}$ of lead respectively and treated with 20:1 concentration of biosurfactant an unidentified bacterium clone JX981747 (Fig. 4c). Comparatively, there was obvious steady increase in copper removal rate in all the concentration ratios in relation to using biosurfactants from 0 . splanchnicus DSM 
20712 than with BC JX981747 with the peak recorded in the highest treatment ratio (20:1) whereas Zinc and Lead removal was high in the later [Figures $3(\mathrm{a}-\mathrm{c})$ and $4(\mathrm{a}-\mathrm{c})$ ].

Table 3: The components of biosurfactant from Odoribacter splanchnicus DSM 20712 depicting peaks by GC-MS analysis

\begin{tabular}{|c|c|c|c|c|c|}
\hline $\mathrm{S} / \mathrm{N}$ & Retention Time & Name of compound/ Library /ID & Molecular formular & Molecular weight & Quality \% \\
\hline 1 & 5.494 & Iso propyl Benzenamine or $\mathrm{N}, \mathrm{N}$-diethylaniline & $\mathrm{C}_{10} \mathrm{H}_{15} \mathrm{~N}$ & 149.120449 & 93 \\
\hline \multirow[t]{2}{*}{2} & 7.583 & 4 -Bromo-3-chloroaniline & $\mathrm{C}_{13} \mathrm{H}_{21} \mathrm{NO}_{2}$ & 223.157228 & 38 \\
\hline & & 2,5-Dimethoxy-4-ethylamphetamine & & & \\
\hline 3 & 7.978 & Phenol, 2,4-bis- (1,1-dimethylethyl) & $\mathrm{C}_{14} \mathrm{H}_{22} \mathrm{O}$ & 206.167066 & 93 \\
\hline 4 & 10.804 & Octadecane & $\mathrm{C}_{18} \mathrm{H}_{38}$ & 254.297351 & 96 \\
\hline 5 & 12.355 & n-Hexadecanoic acid & $\mathrm{C}_{17} \mathrm{H}_{34} \mathrm{O}_{2}$ & 270.25558 & 86 \\
\hline \multirow[t]{3}{*}{6} & 12.470 & Di-n- amyl phthalate & $\mathrm{C}_{18} \mathrm{H}_{26} \mathrm{O}_{4}$ & 306.18311 & 92 \\
\hline & & $\begin{array}{l}\text { 1,2-Benzenedicarboxlic acid butyl 2-methyl propyl ester } \\
\text { OR }\end{array}$ & $\mathrm{C}_{16} \mathrm{H}_{24} \mathrm{O}_{4}$ & 278.15181 & 90 \\
\hline & & 1,2-Benzenedicarboxlic acid butyl cyclohexyl ester & & & \\
\hline \multirow[t]{2}{*}{7} & 12.738 & Octadecane, 3-ethyl-5-(2-ethylbutyl) & $\mathrm{C}_{26} \mathrm{H}_{54}$ & 366.707 & 83 \\
\hline & & Heptacosane & $\mathrm{C}_{27} \mathrm{H}_{56}$ & 380.48202 & 81 \\
\hline
\end{tabular}

Table 4: The components of biosurfactant from an unidentified bacterium clone JX981747 depicting high peaks by GC-

MS analysis

\begin{tabular}{|c|c|c|c|c|c|}
\hline $\mathbf{S} / \mathbf{N}$ & Retention Time & Name of compound/ Library /ID & Molecular formular & Molecular weight & Quality \% \\
\hline 1. & 12.046 & Hexadecanoic acid, methyl ester & $\mathrm{C}_{17} \mathrm{H}_{34} \mathrm{O}_{2}$ & 270.25558 & 99 \\
\hline \multirow[t]{5}{*}{2.} & 12.469 & Di-n- amyl phthalate & $\mathrm{C}_{18} \mathrm{H}_{26} \mathrm{O}_{4}$ & 306.18311 & 92 \\
\hline & & OR & & & \\
\hline & & 1,2-Benzenedicarboxylic acid, butyl 1cyclohexyl ester & $\mathrm{C}_{16} \mathrm{H}_{24} \mathrm{O}_{4}$ & 278.15181 & 90 \\
\hline & & OR & & & \\
\hline & & 1,2-Benzenedicarboxylic acid, butyl 1,2-ethylhexyl ester & & & \\
\hline \multirow[t]{2}{*}{3.} & 13.654 & 9, 12-Octadecadienoic acid (z-z) -, methyl ester & $\mathrm{C}_{19} \mathrm{H}_{34} \mathrm{O}_{2}$ & 294.479 & 99 \\
\hline & & 10, 13-Octadecadienoic acid, methyl ester & & & 99 \\
\hline 4. & 13.705 & 9-Octadecenoic acid, methyl ester (E) & $\mathrm{C}_{19} \mathrm{H}_{36} \mathrm{O}_{2}$ & 296.271 & 99 \\
\hline \multirow[t]{5}{*}{5.} & 13.751 & 11-Octadecenoic acid, methyl ester/Methyl stearate & $\mathrm{C} 19 \mathrm{H} 36 \mathrm{O} 2$ & 296.271 & 99 \\
\hline & & OR & & & \\
\hline & & 9-Octadecenoic acid, methyl ester (E) & $\mathrm{C}_{19} \mathrm{H}_{36} \mathrm{O}_{2}$ & 296.487 & 99 \\
\hline & & OR & & & \\
\hline & & Cis-13- Octadecenoic acid, methyl ester & & & \\
\hline 6. & 13.917 & Octadecanoic acid, methyl stearate & $\mathrm{C}_{19} \mathrm{H}_{38} \mathrm{O}_{2}$ & 298.287 & 99 \\
\hline
\end{tabular}

Table 5: Sugar detection by RFS using BAW 


\begin{tabular}{|c|c|c|c|c|}
\hline & $\mathrm{S} / \mathrm{N}$ & WBS1 & CMS1 & Detected sugar \\
\hline $\mathrm{i}$ & & 12.0 & 12.02 & Glucose/Galactose \\
\hline ii & & 16.96 & - & Mannose \\
\hline iii & & 26.94 & 26.98 & Ribose \\
\hline iv & & 32.01 & 32.00 & Rhamnose \\
\hline
\end{tabular}

Legend:

Sample WBS1 = biosurfactant from Odoribacter splanchnicus DSM 20712

Sample CMS1 = biosurfactant from an unidentified bacterium clone JX981747,

BAW $=$ Butanol-Acetic acid-water, 4:1:5,

$\mathrm{RFS}=$ standard relative fronts for sugars

Table 6: Sugar detection by RFS using BEW

\begin{tabular}{|c|c|c|c|c|}
\hline & $\mathrm{S} / \mathrm{N}$ & WBS1 & CMS1 & Detected sugar \\
\hline $\mathrm{i}$ & & 16.03 & 16.00 & Glucose/Galactose \\
\hline ii & & 23.00 & - & Mannose \\
\hline iii & & 36.03 & 35.97 & Ribose \\
\hline iv & & 37.00 & 37.03 & Rhamnose \\
\hline
\end{tabular}

Legend:

Sample WBS1 = biosurfactant from Odoribacter splanchnicus DSM 20712;

Sample CMS1 = biosurfactant from an unidentified bacterium clone JX981747,

BEW = Butanol-Ethanol-water, 4:1:2.2,

RFS $=$ standard relative fronts for sugars

Comparative Heavy metal removal efficiencies of biosurfactant WBS1-from Odoribacter splanchnicus DSM 20712, CMS1 - from bacterium clone JX981747 and soil washing agents

The percentage metal removal efficiency of the biosurfactants and other soil washing agents used are shown on Figs. 5a-c. The trend observed showed that the percentage metal removal efficiency recorded increased with higher concentrations of the biosurfactants and the test soil washing agents used.

In Fig. 5a, the highest removal percentage observed in 20:1 concentration for copper was $97.49 \%$ (WBS1) followed by $97.38 \%$ (CMS1); of the $15: 1$ concentration is $96.78 \%\left(\mathrm{Ca}\left(\mathrm{NO}_{3}\right)_{2}\right.$ followed by $95.95 \%$ (WBS1); of $10: 1$ concentration is $95.95 \%\left(\mathrm{Ca}\left(\mathrm{NO}_{3}\right)_{2}\right.$ and $\left.\mathrm{NaOH}\right)$ followed by $95.35 \%$ (CMS1) in that order. The varying range of copper removal at $5: 1$ concentration is $92.49 \%, 91.42 \%, 91.06 \%$ and $90.58 \%$ for $\mathrm{Ca}\left(\mathrm{NO}_{3}\right)_{2}, \mathrm{KNO}_{3}, \mathrm{WBS}, \mathrm{CMS} 1$ and $\mathrm{NaOH}$ respectively. However, WBS1 removed more copper $(91.06 \%)$ for this concentration than CMS1 (90.58\%). In addition, at the lowest concentration of 1:1, the soil washing agents removed higher concentration of copper than the biosurfactants. Generally, there is negligible significance difference in copper removal by all the biosurfactants and soil washing agents.

The percentage lead removal is as shown in Fig. 5b. WBS1 removed the highest concentration of lead $(90.22 \%, 87.43 \%, 84.83 \%, 79.24 \%$ and $57.09 \%)$ in all the treatment ratio followed by CMS1 $(90.02 \%$, 
$87.03 \%, 84.23 \%, 78.24 \%$ and $56.89 \%$ ) for $20: 1,15: 1,10: 1,5: 1$ and $1: 1$ ratios respectively. However, of the soil washing agents used in lead removal, $\mathrm{NaOH}$ had the highest values of lead removal at higher treatment concentrations (Fig. 5b).

The zinc removal percentage observed in this study is as shown in figure 5c. Comparatively, of the 20:1, 15:1, 10:1 and 5:1 concentrations $\mathrm{NaOH}$ removed highest concentration of zinc followed by $\mathrm{KNO}_{3}$, $\mathrm{Ca}\left(\mathrm{NO}_{3}\right)_{2}, \mathrm{CMS} 1$ and WBS1 in that order except at 1:1 ratio where $\mathrm{Ca}\left(\mathrm{NO}_{3}\right)_{2}$ had the highest value.

Comparatively, the test biosurfactants used in this study removed copper and lead more than the soil washing agents whereas the later removed zinc more than the former.

\section{Discussions}

\section{Crude Biosurfactant production and characteristics}

Biosurfactants are indeed good bio-products with great diversity and broad spectrum of functions and environmental applications. There various sources could be from contaminated water, soil and most importantly from microorganisms (Reis et al., 2013). In this study, crude biosurfactants were obtained from two major isolates amongst others namely Odoribacter splanchnicus DSM 20712 and an unidentified bacterium clone JX981747. The possible production and recovery of crude biological surfactants from microorganisms as observed in this study corroborates with the findings of Anandaraj and Thivakaran, (2010) who obtained $0.122 \mathrm{~g}$ of biosurfactant from Pseudomonas sp. grown in $50 \mathrm{ml}$ of R2B broth with $1 \mathrm{ml}$ of petrol as carbon source. It also supports the findings of Maneerat et al., (2006) who also proved the possibility of extracting crude biosurfactant from isolates during his experiment with marine bacterium Myroides sp and extracted $2.64 \mathrm{~g}$ of a crude oil emulsifier from $10 \mathrm{~L}$ of cultured strain SMI. This current study is in agreement that different yields of crude biosurfactant can be precipitated and extracted from the culture broth.

The biosurfactants produced from Odoribacter splanchnicus DSM 20712 and the unidentified bacterium clone JX981747 in this study showed the presence of rhamnose sugar, and fatty acid component. The major component of $O$. splanchnicus, di-n- amyl phthalate as regards its structure will remove more metals by chelating and less of hydrocarbon because of the short aliphatic chain whereas the major component of bacterium clone JX981747, which is 9-Octadecenoic acid- a methyl ester, will remove less metals and function better as hydrocarbon removal because of the chain length.

\section{Heavy metal removal from spiked soil using crude biosurfactant}

Heavy metal removal from terrestrial environment is one of the key areas in environmental management and clean up operations where the significance of biosurfactants has not been explored in depth (Luna et al., 2016). The result of this study evidently depict that the test heavy metals (copper, lead and zinc) 
removal rate was effective and high with increase in concentration of the biological surfactants tested. This corroborates with the report made by Maier at al., (2001) who studied biosurfactant removal of metals from spiked sewage sludge which was anaerobically digested. They equally had high rate of copper recovery in solution spiked with $2000 \mathrm{mg} / \mathrm{kg}$ treated with $50 \mathrm{mM}$ rhamnolipid. The findings of this study equally established this fact, and support the findings made by Mulligan et al., (2001; 2004). In their study, they also observed high copper removal (70\%) proving the feasibility metal removal with amnionic biosurfactants in batch washing experiments.

Furthermore, the high rate of metal removal as observed in this study have shown that surfactants could remove metals by ion exchange precipitation, dissolution and counterion association with the crude sugar surfactant, depicting superior performance similar to previous reports (Mulligan et al., 1999, 2001, 2004 and Qi et al., 2018). Generally, the concentration of biosurfactant have been observed to be a critical factor influencing heavy metal removal efficiency in this study and elsewhere (Mulligan et al., 2001 and Qi et al., 2018).

\section{Efficiencies of biosurfactant and soil washing agents in heavy metal removal}

Mulligan et al, (1999) showed the feasibility of removing cadmium, lead, and zinc with $2 \%$ anionic biosurfactants surfactin from soil that is low in exchangeable metal fractions. The use of $\mathrm{NaOH}$ alone removed $20 \%$ copper, $10 \%$ zinc while surfactin biosurfactant removed $70 \%$ copper and $25 \%$ zinc. Chakrabarti, (2015) noted lead removal using biosurfactant produced by a Bacillus sp. SJ301 which removed nearly $2-3 \%$ lead from a highly toxic $100 \mathrm{ppm}$ lead solution. This current study equally established the feasibility of $\mathrm{Cu}, \mathrm{Pb}, \mathrm{Zn}$ removal with biosurfactant depicting increase in the concentration of biosurfactant and its additional effect on the percentage metal removal efficiency. This also in agreement with the findings of Hong et al., (2002) and Mulligan et al., (2007) who observed that the removal percentage of $\mathrm{Cu}, \mathrm{Zn}$ and $\mathrm{Ni}$ in the soil increased linearly with increasing concentration of rhamnolipid used. The recorded values are indications that biosurfactant can be used to remove metals from contaminated samples. Maier et al., (2001) in their study also observed the effects of biosurfactants rhamnolipid and surfactin in metal removal in a historically contaminated soil by $10 \mathrm{mM}$ purified rhamnolipid adjusted to $\mathrm{pH} 7.1$ compared with other soil washing agents, KNO3 solution adjusted to the same ionic strength as the rhamnolipid solution and $50 \mathrm{mM} \mathrm{Ca(NO3)2.} \mathrm{The} \mathrm{rhamnolipid} \mathrm{removed} \mathrm{a} \mathrm{total}$ of 14 to $15 \%$ of the lead from each historically contaminated soil in 10 extractions. Their study in consonance with the findings of this study showed that rhamnolipid containing biological surfactant greatly enhanced metal removal than with chelators $\left(\mathrm{KNO}_{3}\right.$ or $\left.\mathrm{Ca}\left(\mathrm{NO}_{3}\right)_{2}\right)$. This study, irrespective of the source and history of contamination of soil established the feasibility of biosurfactant removal of copper, zinc and lead contaminants.

\section{Conclusion}


The two biosurfactants produced from Odoribacter splanchnicus DSM 20712 and unidentified bacterium clone JX981747 recorded the highest emulsification index and equally showed higher levels of percentage metal removal. Biosurfactant from 0. splanchnicus efficiently removed copper more than that from BC JX981747 whereas that from unidentified bacterium clone JX981747 removed both zinc and lead efficiently more than does the former in the spiked soil. Nevertheless, both significantly removed the test metals with negligible difference achieved possibly by forming complex at the polar end of the micelles with the metals and as a result these metals are desorbed out of the contaminating matrix. Furthermore, the test biosurfactants studied showed high levels of copper and lead removal than zinc when compared with the test soil washing agents $\left(\mathrm{KNO}_{3}\right), \mathrm{Ca}(\mathrm{NO} 3)_{2}$ and $\mathrm{NaOH}$ used in this study. Biosurfactants have therefore proved to be efficient in metal removal and since they are biodegradable, the culture medium for the optimum production of these biosurfactants should be formulated to enhance high production yield. In addition, its exploitation should be encouraged for large scale industrial and environmental applications.

\section{Abbreviations}

WBS1- biosurfactant from Odoribacter splanchnicus DSM 20712 isolated from waste battery dump soil CMS1 - biosurfactant from bacterium clone JX981747 isolated from cassava mill soil GC-MS - Gas Chromatography Mass Spectroscopy

$E_{24}$ - Emulsification index

\section{Declarations}

\section{Acknowledgements}

The authors acknowledge the effort of the laboratory staff Anusim, Onyinyechi of Department of Biotechnology, Federal University of Technology Owerri and Eze, Faustina of FOWN molecular Biology Laboratory, Lagos Nigeria, for their help during the laboratory analyses.

\section{Authors' contributions}

The corresponding author (TEO) conceptualize the idea, designed the work, conducted analysis with her team at different stages, interrelated data and results for this work, and wrote this paper. TEO and the other authors are accountable for all aspects of the work in ensuring that questions related to the accuracy or integrity of any part of the work hence the essence of a team comprising a microbial biotechnologist and chemist. The authors read through and I approved the final manuscript. The authors are prepared to take public responsibility for the work. 


\section{Funding}

This research did not receive any specific grant from funding agencies in the public, commercial, or notfor-profit sectors.

\section{Availability of data and materials}

The data that support the findings of this study are available from the corresponding author (TEO), upon reasonable request.

\section{Ethics approval and consent to participate}

This research does not contain any studies on human participants or animals performed by any of the authors.

\section{Consent for publication}

I, Toochukwu Ekwutosi OGBULIE (TEO), the corresponding author declare that it is my study and I developed the manuscript titled 'Comparative heavy metal removal efficiencies of biosurfactants produced by Odoribacter splanchnicus DSM 20712, bacterium clone JX981747 and soil washing agents". The authors hereby grant Journal of Bioresources and Bioprocessing full right to the manuscript to publish, revise, reproduce and distribute. The authors are agreeing that the submitted article retains the property/ copyright of Bioresources and Bioprocessing Journal.

\section{Declaration of conflict of interest}

The authors declare that they have no competing interests.

\section{References}

Adriano DC (2003) Trace Elements in Terrestrial Environments: Biogeochemistry, Bioavailability and Risks of Metals. (2nd edition). Springer, New York, NY, USA.

AOAC (2005) Official method of analysis ( $18^{\text {th }}$ Edition), Association of Officiating Analytical Chemists International, Maryland, USA. pp. 2.3 - 2.8; 46.4.

Asci Y, Nurbas M, Acikel YS (2007) Sorption of Cd (II) onto kaolin as a soil component and desorption of Cd(II) from kaolin using rhamnolipid biosurfactant. J Haz Mat 139(1): 50-56

Asci Y, Nurbas M, Acikel YS (2008) A comparative study for the sorption of Cd (II) by soils with different clay contents and mineralogy and the recovery of $\mathrm{Cd}(\mathrm{II})$ using rhamnolipid Biosurfactant. J Haz Mat 154(1-3): 663-673. 
Chakrabart S (2015) Bacterial biosurfactant: Characterization, antimicrobial and metal remediation properties. Dissertation, Department of life science National Institute of Technology Rourkela Odisha. retrieved Nov 2018 from http://ethesis.nitrkl.ac.in/3113/.pp. 1-62

Chu W, Chan KH (2003) The mechanism of the surfactant aided soil washing system for hydrophobic and partial hydrophobic organics. Sci Total Environ 307(1-3): 83-92.

Davis AP, Singh I (1995) Washing of Zinc (II) from contaminated soil column. J Environ Eng 121(2): 174-

Dehghan-Noudeh G, Housaindokht M, Bazzaz BSF (2005) Isolation, characterization, and investigation of surface and hemolytic activities of a lipopeptide biosurfactant produced by Bacillus subtilis ATCC 6633 . J Microbiol 43(3): 272-276.

Dermont G, Bergeron M, Mercier G, Richer-Lafleche M (2008) Soil washing for metal removal: A review of physical/chemical technologies and field applications. J Harzard Mater 152(1):1-31

Fiebig SD, Chung JC, Lee ST (1997) Biodegradation of polychlorinated biphenys (PCBs) in the presence of a bioemulsifier produced on sunflower oil. Biodeg 8: 67-75.

Gao Y, He J, Ling W, Hu H, Liu F (2003) Effects of organic acids on copper and cadmium desorption fromcontaminated soils. Environ Intl 29(5): 613-618.

Gombert D (1994) Soil washing and radioactive contamination. Environ Prog 13(2): 138-142.

Harborne AJ (1998) Phytochemical methods: A guide to modern techniques of plant analysis. $8^{\text {th }}$ edition. Springer Netherlands publishers ISBN 976-0-412-57260-9. pp. 1-302

Hong KJ, Tokunaga S, Kajiuchi T (2002) Evaluation of remediation process with plant-derived biosurfactant for recovery of heavy metals from contaminated soils. Chemospher 49(4): 379-387.

Ivanković T, Hrenović J (2010) Surfactants in the environment. Arh Hig Rada Toksikol 61: 95-110. DOI: 10.2478/10004-1254-61-2010-1943

Khan S, Cao Q, Zheng YM, Huang YZ, Zhu YG (2008) Health risks of heavy metals in contaminated soils and food crops irrigated with wastewater in Beijing, China. Environ Poll 152(3): 686-692.

Kumari B, Singh SN, Singh DP (2012) Characterization of two biosurfactant producing strains in crude oil degradation. Proces Biochem 47: 2463-2471.

Kirpichtchikova TA, Manceau AL, Spadini F, Panfili M, Marcus A, Jacquet T (2006) Speciation and solubility of heavy metals in contaminated soil using X-ray microfluorescence, EXAFS spectroscopy, chemical extraction, and thermodynamic modeling. Geo Cosmoc Acta 70(9): 2163-2190. 
Ling W, Shen Q, Gao Y, Gu X, Yang Z (2007) Use of bentonite to control the release of copper from contaminated soils. Austr J Soil Res 45(8): 618-623.

Luna J.M, Rufino RD, Sambbo CA (2016) Biosurfactant from Candida sphaerica UCP0995 exhibiting heavy metal remediation properties. Proc. Safety Environ. Protcl. 102: 558-566

Maier RM, Neilson JW, Artiola JF, Jordan FL, Glenn EP, Descher SM (2001) Remediation of metalcontaminated soil and sludge using biosurfactant technology. Intl J Occuptl Med Environtl Health 14(3): 241-248.

Maslin P, Maier RM (2000) Rhamnolipid-enhanced mineralization of phenanthrene in organic-metal cocontaminated soils. Biorem J 4(4): 295-308.

Maturi K, Reddy KR (2008) Extractants for the removal of mixed contaminants from soils. Soil Sed Cont17(6): 586-608.

McLaughlin MJ, Zarcinas BA, Stevens DP, Cook N (2000a) Soil testing for heavy metals. Comm Soil Sci Plant Anal 31(11-14): 1661-1700.

McLaughlin MJ, Hamon RE, McLaren RG, Speir TW, Rogers SL (2000b) Review: A bioavailability-based rationale for controlling metal and metalloid contamination of agricultural land in Australia and New Zealand. Austr J Soil Res 38(6): 1037-1086.

Mulligan CN, Yong RN, Gibbs BF, James S, Bennett HPJ (1999) Metal removal from contaminated soil and sediments by the biosurfactant surfactin. Environ Sci Technol 33(21): 3812-3820.

Mulligan CN, Yong RN, Gibbs BF (2001) Heavy metal removal from sediments by biosurfactant. J. Hazard Mat 85: 111-125

Mulligan CN, Yong RN, Gibbs BF (2004) On the use of biosurfactants for the removal of heavy metals from oil contaminated soil. Environ Prog 18(1): https://doi.org/10-1002/ep.670180140

Oberbremer A, Muller-Hurtig R, Wagner F (1990) Effect of the addition of microbial surfactants on hydrocarbon degradation in soil population in a stirred reactor. Appl Microbiol Biotechnol 32:485-489.

Ogbulie TE, Ogbulie JN, Umezuruike I (2008) Biodegradation of detergents by aquatic bacterial flora from Otammiri River, Nigeria. Afr J Biotech 7(6): 824-830. http://www.academicjournals.org/AJB

Ogbulie TE, Nwigwe HC, Iwuala MOE, Okpokwasili GC (2010) Study on the use of Monoculture and Multispecie systems in Bioaugumentation of crude oil Contaminated Agricultural soil. Nig J Microbiol 24(1): 2160-2167.

Ogbulie TE (2011) Phytoextraction of Nickel, Chromium, Lead and Copper from Crude oil polluted Agricultural soil. Intl J Tropl Agric Food Sys 5(2): 99-106. 
Okore CC, Nwaehiri LU, Mbanefo ON, Ogbulie TE, Ugenyi AU, Ogbuka IB, Ejele AE, Okwujiako IA (2017a) Study on the production and antibacterial activities of biosurfactant produced from some bacterial species. Intl J Adv Res 5(7): 581-586

Okore CC, Nwaehiri LU, Mbanefo ON, Ogbulie TE, Ugenyi AU, Ogbuka IB, Ejele AE, Okwujiako IA (2017b) Study on effect of monovalent and divalent salts on the production of biosurfactant and emulsification index. Intl J Adv Res 5(6): 1875-1881

Okore CC, Nwaehiri LU, Mbanefo ON, Ogbulie TE, Ugenyi AU, Ogbuka IB, Ejele AE, Okwujiako IA (2017c) Study on microbial diversity of biosurfactant producing bacteria from contaminated environmental samples. Intl J Adv Res 5(6): 1387-1396

Okore CC, Nwaehiri LU, Mbanefo ON, Ogbulie TE, Ugenyi AU, Ogbuka IB, Ejele AE, Okwujiako IA (2017d) The use of random amplified polymorphic DNA (RAPD) to study the genetic variation of biosurfactant producing bacteria. Acad J Sci 07(03): 267-286

Okore CC, Mbanefo ON, Onyekwere BC, Onyewenjo S, Abba-Father CAM (2013) Isolation and characterization of biosurfactants producing bacteria from oil polluted soil. J Nat Sci Res www.iiste.org. 3(5): 119-122

Płociniczak MP, Płaza GA, Seget ZP, Cameotra SS (2011) Environmental Applications of Biosurfactants: Recent Advances. Intl J Mol Sci 12: 633-654.

Qi X, Xu X, Zhong C, Jiang T, Wei W, Song X (2018) Removal of Cadmium and Lead from contaminated soil using sophorolipids from fermented culture of Starmerella bombicola CGMCC 1576 fermentation. Intl J Environ Res Pub Health 15: 1-12

Roane TM, Pepper IL, Miller RM (1996) Microbial remediation of metals. In: Crawford RL, Crawford DL, (eds.) Bioremediation: Principles and Applications. United Kingdom: Cambridge Univ. Press. pp. 312-40.

Rufino RD, Rodrigues GIB, Campos-Takaki GM, Sarubbo LA, Ferreira SRM (2011) Application of a yeast biosurfactant in the removal of heavy metals and hydrophobic contaminant in a soil used as slurry barrier. Appl Environ Soil Sci. Article ID 939648. doi:10.1155/2011/939648. pp.1-7.

Tejowulan RS, Hendershot WH (1998) Removal of trace metals from contaminated soils using EDTA incorporating resin trapping techniques. Environ Pollutn 103(1):135-142.

USEPA (1990) Engineering bulletin: Soil washing treatment. Tech. Rep. EPA/540/2-90/017, Office of Emergency and Remedial Response, United States Environmental Protection Agency. Washington, DC, USA. 
Wood AL, Bouchard DC, Brusseau ML, Rao PSC (1990) Cosolvent effects on sorption and mobility of organic contaminants in soils. Chemosph 21(4-5): 575-587.

Yuste L, Corbella ME, Turiegano MJ, Karison U, Puyet A, Rojo F (2000) Characterization of bacteria strains able to grow on high molecular mass residues from crude oil processing. FEMS Microbial Ecol 32:69-75.

Zhang H, Dang Z, Zheng LC, Yi XY (2009) Remediation of soil co-contaminated with pyrene and cadmium by growing maize (Zea mays L.). Intl. J. Environ. Sci. Technol. 6(2), 249-258.

Zhang MK, Liu ZY, Wang H (2010) Use of single extraction methods to predict bioavailability of heavy metals in polluted soils to rice. Comm Soil Sci Plant Anal 41(7): 820-831.

Zhao Q, Kaluarachchi J (2002) Risk assessment at hazardous waste-contaminated sites with variability of population characteristics. Environ Intl 28(1-2): 41-53.

\section{Figures}
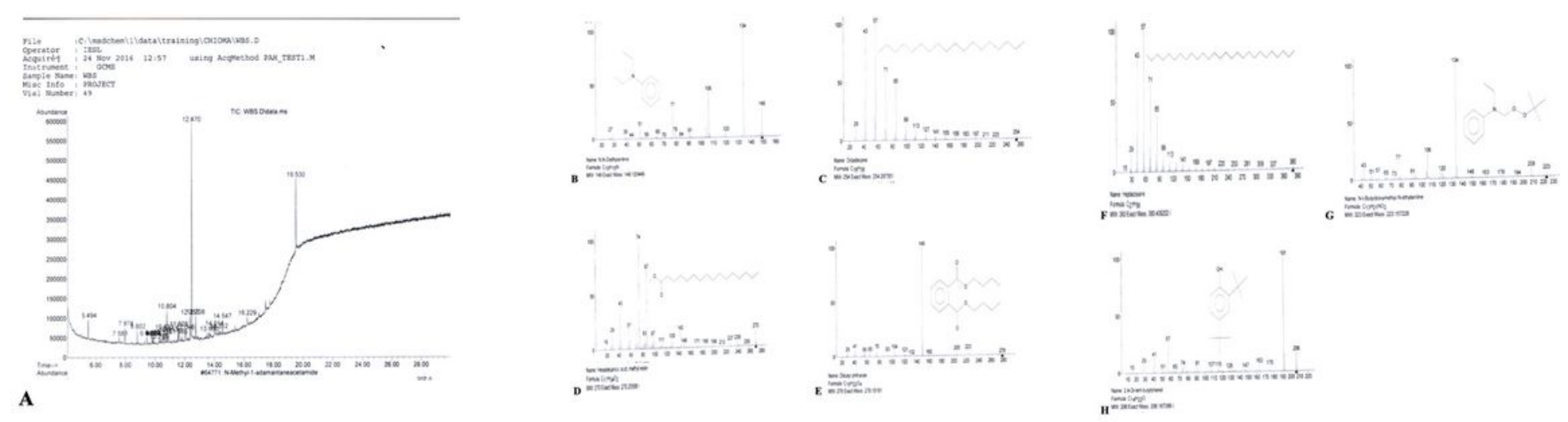

Figure 1

A: Chromatogram of biosurfactant from Odoribacter splanchnicus DSM 20712. (B-H): Mass spectral of the components of biosurfactant from Odoribacter splanchnicus DSM 20712 


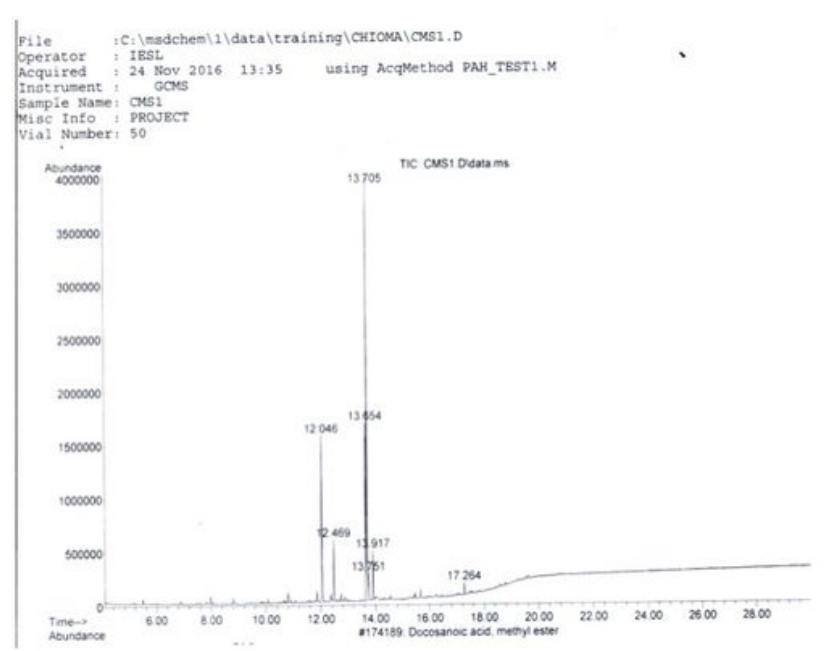

$\mathbf{A}$

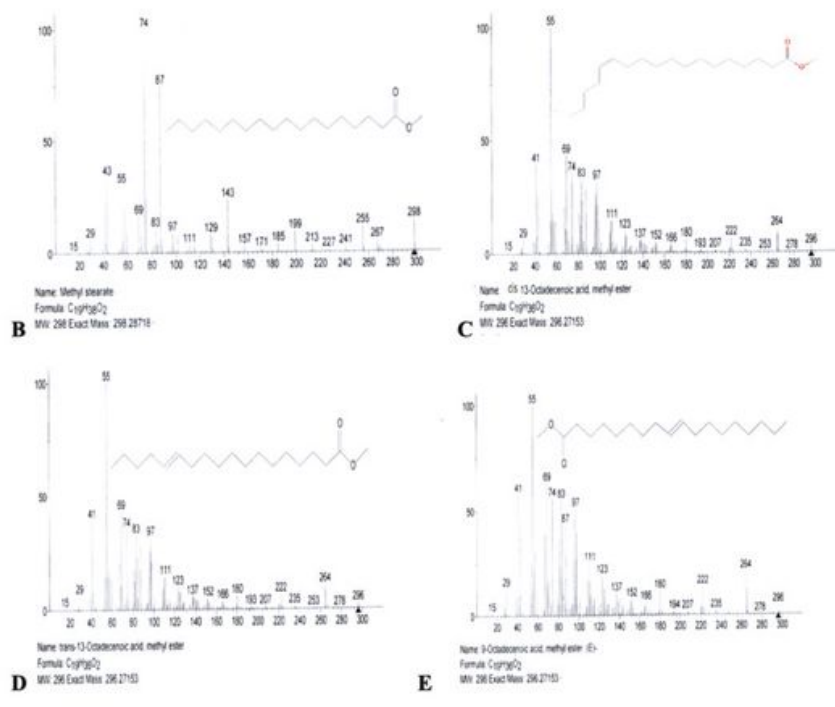

Figure 2

A: Chromatogram of biosurfactant from the unidentified bacterium clone JX981747. (B-E): Mass spectral of the components of biosurfactant from the unidentified bacterium clone JX981747 

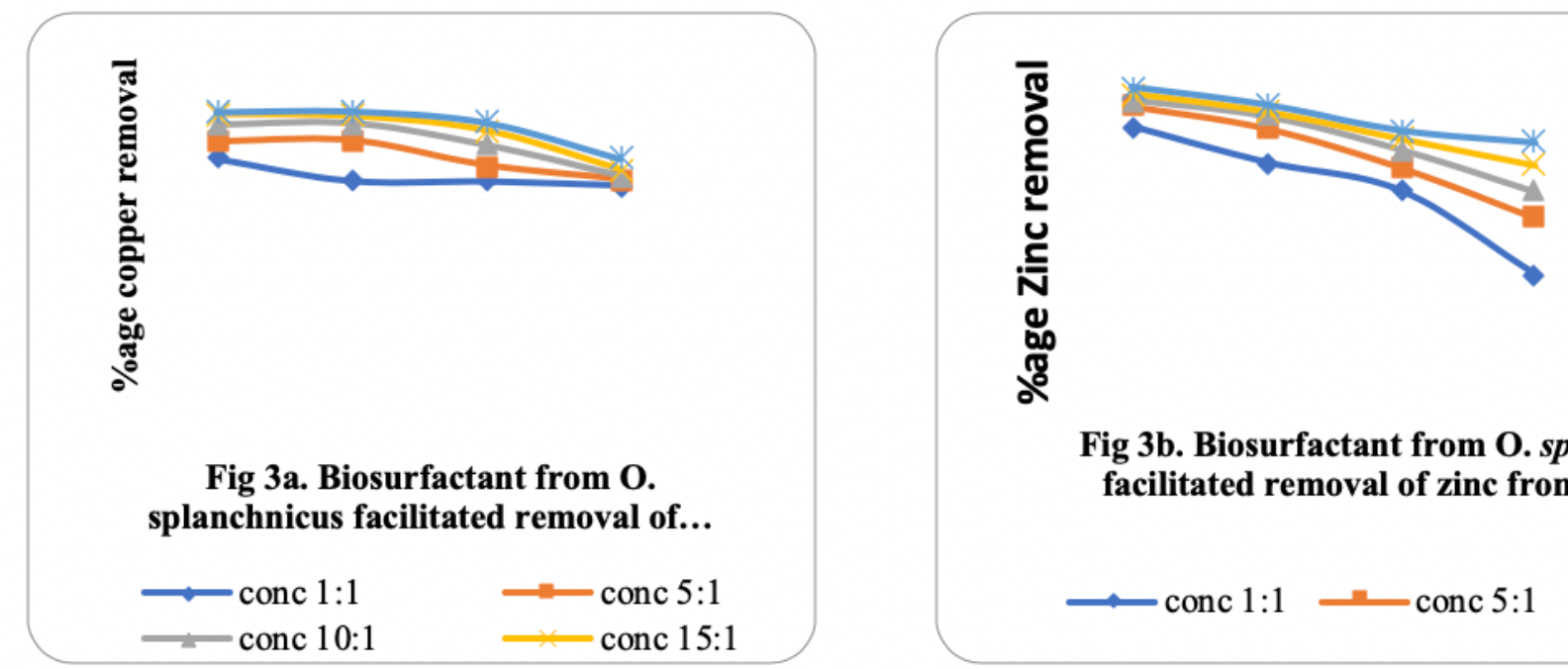

Fig 3b. Biosurfactant from O. splanchnicus facilitated removal of zinc from waste...
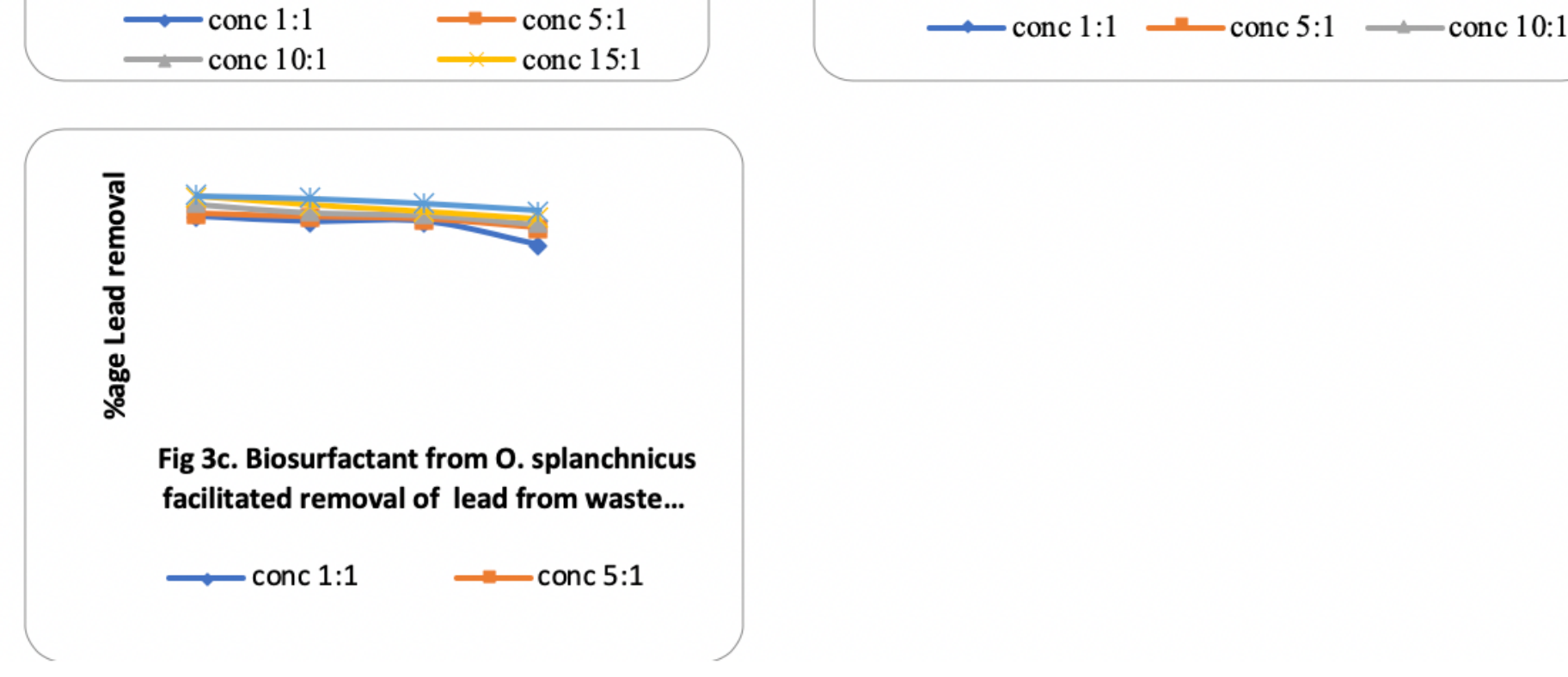

Figure 3 

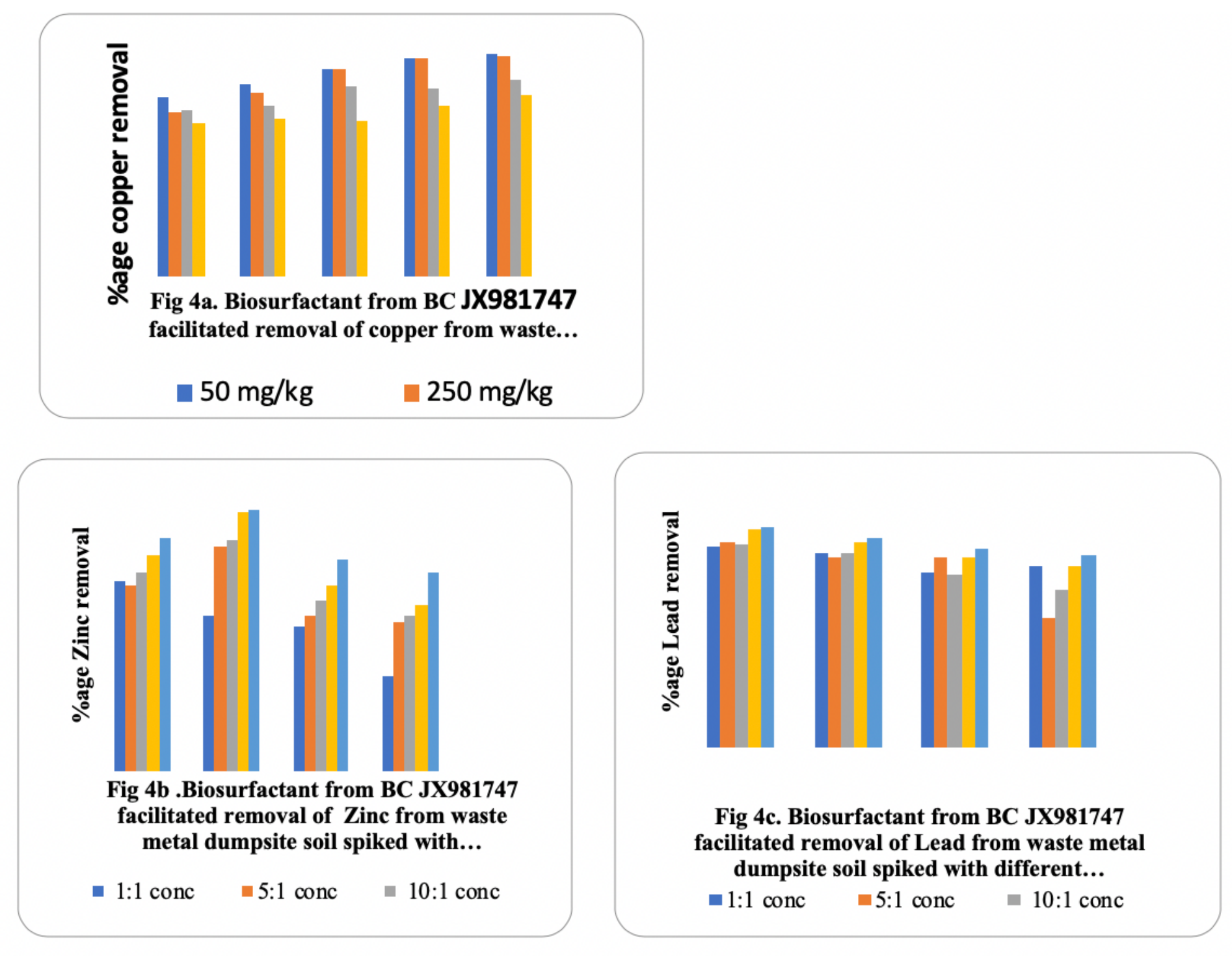

Figure 4 


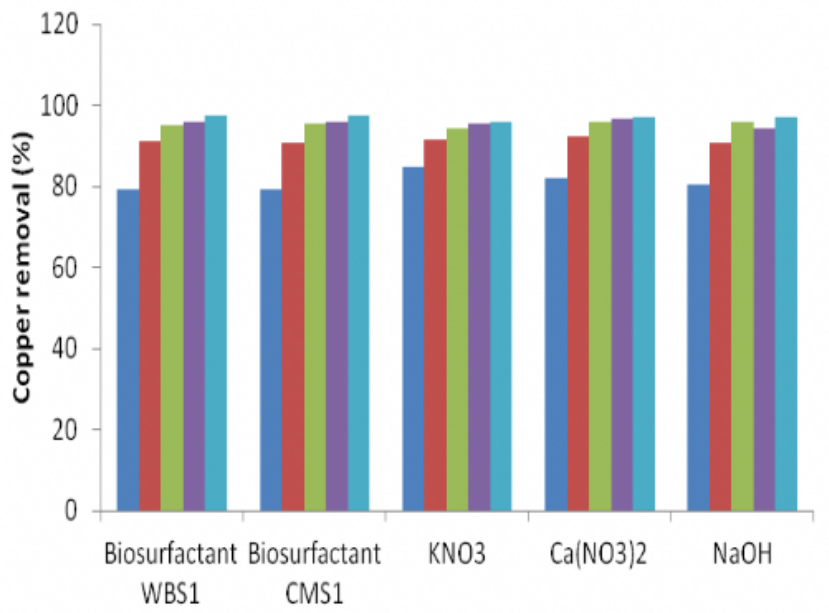

Fig. 5a: Efficiencies of Biosurfactants and soil washing agents in removal of copper from test soil

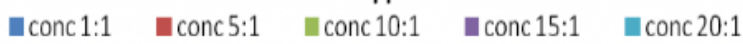

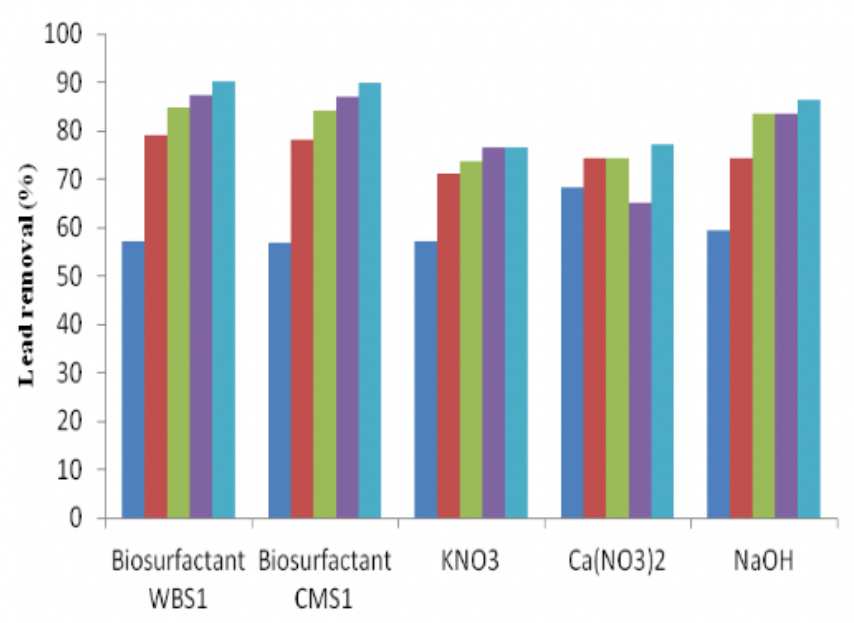

Fig. 5b: Efficiencies of Biosurfactants and soil washing agentsin removal of lead from test soil

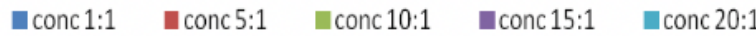

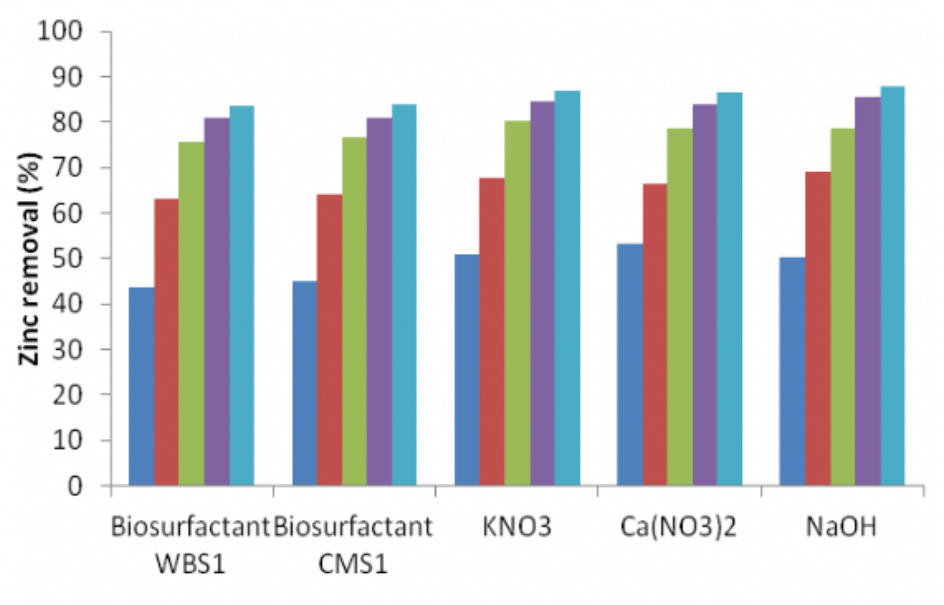

Fig. $5 \mathrm{c}$ : Efficiencies of biosurfactants and soil washing agents in removal of zinc from test soil

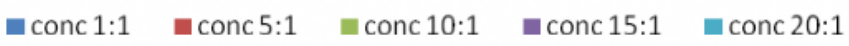

\section{Figure 5}

WBS1- biosurfactant from Odoribacter splanchnicus DSM 20712. CMS1 - biosurfactant from bacterium clone JX981747.

\section{Supplementary Files}

This is a list of supplementary files associated with this preprint. Click to download.

- OGBULIEETAL2020GRAPHICALABSTRACTFORBBJ.pdf 